\title{
Cyberbullying: a worldwide trend of misusing technology to harass others
}

\author{
E. Kraft \\ School of Business, Georgian Court University, USA
}

\begin{abstract}
Cyberbullying: a worldwide trend of misusing technology to harass others.

Technology has led to a new form of bullying in the $21^{\text {st }}$ century called cyberbullying. Cyberbullying is using the Internet or a cell phone to harass a victim with pictures and text. There have been reports in the media of youth being harassed by e-mail, postings on websites, instant messages, and mobile text messages worldwide.

This paper summarizes findings about the prevalence and effects of cyberbullying from studies conducted in Australia, Canada, the United Kingdom, and the United States. Results of the studies were compared to media reports of cyberbullying and traditional bullying research. Strategies to stop and prevent cyberbullying were discussed.

The percentage of respondents experiencing incidents of cyberbullying in the studies ranged from $10 \%$ to $42 \%$. The mobile phone was the predominant method of cyberbullying in Australia and the United Kingdom, whereas the Internet was the favoured method in the United States and Canada.

Some victims of cyberbullying have been driven to suicide while others remain unaffected by it. The most common feelings of victims were anger, sadness, frustration, and fear. Independent studies in the United States, United Kingdom, and Canada documented that parents and children do not discuss cyberbullying.

It is recommended that schools establish and post acceptable use policies for the Internet. Parents need to be educated about cyberbullying so that they can impose consequences if their child is harassing another child. Real time computerized reporting systems such Text Someone can be used to augment reporting of incidents. Showing students how mobile phone calls and e-mail messages can be traced may deter cyberbullying.
\end{abstract}

Keywords: cyberbullying, cyber-bullying, mobile phone bullying, online bullying, online harassment, cyberharassment, cell phone bullying, bullying, harassment, bullied online. 


\section{Introduction}

There has been research conducted in the United States, United Kingdom, Europe, Canada, and Australia about how children and adolescents are using the Internet. The Internet and mobile phones have led to a new form of bullying in the $21^{\text {st }}$ century called cyberbullying. Cyberbullying is an online behaviour that has manifested itself world wide among youth. This paper analyzes international findings about the prevalence and effects of cyberbullying worldwide. Technological and behavioural intervention strategies for preventing and stopping cyberbullying are discussed.

\section{Cyberbullying defined}

Cyberbullying is using the Internet or a cell phone to harass another person with text and pictures. Electronic communication methods used for cyberbullying include e-mail, instant messaging (IM), text messaging (SMS) by mobile phones, chat, websites, online web logs, online personal polling sites, and pagers $[13,14]$. Examples of cyberbullying are sending threatening or offensive emails, instant messages, or cell phone text messages directly to the victim. Mass cruel or embarrassing e-mail or text messages can be sent to peers about the victim by mobile phone or e-mail. Some cyberbullies steal passwords to hack into the victim's computer or e-mail account. They harass others using the victim's IM screen name or e-mail account so as not be held accountable for their actions [14]. Dedicating a website to degrading the victim is another tactic of cyberbullies. Camera phones have become the latest technology used by cyberbullies to take pictures of a victim naked in locker rooms or bathrooms and post the pictures on the web or send them to others via e-mail or cell phone $[3,15]$. Filming a violent attack such as a beating using a third generation mobile phone and posting the clip on the web is the newest cyberbullying trend called "Happy Slapping" [4]. Cyberbullying is usually considered to be repeated harassment [13]; however, a single incident [16], such as a "happy slapping" attack, can have devastating effects on the victim.

\section{International research findings about cyberbullying}

Table 1, on the next page, summarizes international findings from studies conducted in Australia, Canada, United Kingdom, and the United States that estimate the prevalence of cyberbullying. The results are from studies that investigate how children and adolescents use the Internet, as well as, studies that exclusively address cyberbullying. Column 1 of the table designates the country where the study was conducted. The exact question that was answered by the respondents is quoted in the second column. Column 3 lists the percentage of respondents indicating an affirmative response to the statement or question made in column 2. Column 4 lists the age or grade level of the participants in the study with the year the study took place in parentheses below. The year of the Beran and $\mathrm{Li}$ [6] survey and Li [18] study are unknown. The final column lists the source of the study. 
Table 1: $\quad$ Percentage of respondents reporting incidents of cyberbullying.

\begin{tabular}{|c|c|c|c|c|}
\hline Country & Question & Percent & Grade or Age & Source \\
\hline Australia & $\begin{array}{l}\text { "Received threatening } \\
\text { messages on their } \\
\text { mobile phone" }\end{array}$ & $10 \%$ & $\begin{array}{l}\text { Grades } 7-12 \\
(2004)\end{array}$ & $\begin{array}{l}\text { Australian } \\
\text { Psychological } \\
\text { Society [7] }\end{array}$ \\
\hline Canada & $\begin{array}{l}\text { "e-mailed } \\
\text { material that } \\
\text { hateful things } \\
\text { others" }\end{array}$ & $25 \%$ & $\begin{array}{l}\text { Grades 4-11 } \\
(2001)\end{array}$ & $\begin{array}{l}\text { Media } \\
\text { Awareness } \\
\text { Network [17] }\end{array}$ \\
\hline Canada & $\begin{array}{l}\text { Calculated from } \\
\text { percentage of victims } \\
\text { of bullying who were } \\
\text { bullied online }\end{array}$ & $9.5 \%$ & $\begin{array}{l}\text { Grades 7-12 } \\
(2005)\end{array}$ & $\begin{array}{l}\text { Media } \\
\text { Awareness } \\
\text { Network [10] }\end{array}$ \\
\hline Canada & $\begin{array}{l}\text { "Experienced cyber- } \\
\text { harassment once or } \\
\text { twice" }\end{array}$ & $35 \%$ & Grades 7-9 & Beran \& Li [6] \\
\hline Canada & $\begin{array}{l}\text { "Experienced cyber- } \\
\text { harassment at least a } \\
\text { few times" }\end{array}$ & $23 \%$ & Grades 7-9 & Beran \& Li [6] \\
\hline Canada & $\begin{array}{l}\text { "I have been cyber- } \\
\text { bullied (eg. via email, } \\
\text { chat room, cell phone)" }\end{array}$ & 24.59 & Grade 7 & $\operatorname{Li}[18]$ \\
\hline $\begin{array}{l}\text { United } \\
\text { Kingdom }\end{array}$ & $\begin{array}{l}\text { "Bullied or threatened } \\
\text { online by PC or mobile } \\
\text { phone }\end{array}$ & $25 \%$ & $\begin{array}{l}\text { Ages 11-19 } \\
(2002)\end{array}$ & $\begin{array}{l}\text { National } \\
\text { Children's Home } \\
{[19]}\end{array}$ \\
\hline $\begin{array}{l}\text { United } \\
\text { Kingdom }\end{array}$ & $\begin{array}{l}\text { "Have you ever been } \\
\text { bullied or threatened by } \\
\text { someone using any of } \\
\text { the following- e-mail, } \\
\text { Internet chat room, or } \\
\text { mobile phone text } \\
\text { messaging?" }\end{array}$ & $20 \%$ & $\begin{array}{l}\text { Ages 11-19 } \\
(2005)\end{array}$ & $\begin{array}{lll}\mathrm{NCH} & \& & \text { Tesco. } \\
{[8]} & & \end{array}$ \\
\hline $\begin{array}{l}\text { United } \\
\text { Kingdom }\end{array}$ & $\begin{array}{l}\text { "Received nasty } \\
\text { comments via e-mail, } \\
\text { chat, instant messaging } \\
\text { or text messaging" }\end{array}$ & $33 \%$ & $\begin{array}{l}\text { Ages 9-19 } \\
(2002-2003)\end{array}$ & Livingstone [9] \\
\hline $\begin{array}{l}\text { United } \\
\text { States }\end{array}$ & "Been bullied online" & $42 \%$ & $\begin{array}{l}\text { Grades 4-8 } \\
(2003-2004)\end{array}$ & i-SAFE [2] \\
\hline $\begin{array}{l}\text { United } \\
\text { States }\end{array}$ & $\begin{array}{l}\text { "Bullied more than } \\
\text { once online" }\end{array}$ & $25 \%$ & $\begin{array}{l}\text { Grades 4-8 } \\
(2003-2004) \\
\end{array}$ & i-SAFE [2] \\
\hline $\begin{array}{l}\text { United } \\
\text { States }\end{array}$ & $\begin{array}{lll}\text { "received mean } & \text { or } \\
\text { threatening } & \text { e-mail } & \text { or } \\
\text { other messages" } & \\
\end{array}$ & $21 \%$ & $\begin{array}{l}\text { Grades 4-8 } \\
(2003-2004)\end{array}$ & i-SAFE [2] \\
\hline $\begin{array}{l}\text { United } \\
\text { States }\end{array}$ & $\begin{array}{l}\text { "Experienced cyber- } \\
\text { bullying" }\end{array}$ & $34 \%$ & $\begin{array}{l}\text { Adolescents } \\
(2005)\end{array}$ & $\begin{array}{ll}\text { Hinduja } & \text { and } \\
\text { Patchin [7] } & \\
\end{array}$ \\
\hline $\begin{array}{l}\text { United } \\
\text { States }\end{array}$ & $\begin{array}{l}\text { "threatened and } \\
\text { embarrassed about a } \\
\text { posting or a message" } \\
\text { or "feel worried or } \\
\text { threatened about online } \\
\text { harassment." }\end{array}$ & $6 \%$ & $\begin{array}{l}\text { Ages 10-17 } \\
(1999-2000)\end{array}$ & $\begin{array}{l}\text { Office of } \\
\text { Juvenile Justice } \\
\text { Department [20] }\end{array}$ \\
\hline
\end{tabular}




\subsection{Prevalence of cyberbullying}

Traditional bullying prevalence is dependent upon age and grade level [21]. Bullying incidents occur most often in elementary school and frequently in middle school [21, 22], while decreasing in high school [22]. Some of the cyberbullying studies reviewed focused on the middle or upper grades, while others covered both levels. Parry Aftab, executive director of wiredsafety.org, a United States online safety group, maintains that cyberbullying occurs primarily from ages 9 to 14 and then escalates to online sexual harassment after age 14 $[14,22]$. The studies also phrased questions about cyberbullying differently that could affect the responses. In particular, when the word threatened was part of the question the percentage of affirmative responses decreased. Questions that were more specific requiring less interpretation on the part of the respondent had higher affirmative responses. The questions that asked about incidents occurring multiple times had lower affirmative response rates than those asking about a single incident.

The prevalence of cyberbullying is hard to determine just as statistics for traditional bullying are difficult to estimate. A review of international studies during the 1980's and 1990's by the Community Oriented Policing Services Office (COPS) of the U.S. Department of Justice discovered that " 8 to 38 percent of students are bullied with some regularity"[22]. The percentage of respondents experiencing incidents of cyberbullying in the studies ranged from $10 \%$ [1] to $42 \%$ [2] which is close to the range reported for traditional bullying incidents.

\subsubsection{Prevalence of reported cyberbullying from studies conducted in Australia}

The Australian Psychological Society conducted a study about the mobile phone use among adolescents. The results listed in the first row of table 1 were that $10 \%$ of 258 students in grades 7-12 from Melbourne and Sydney had received threatening calls on their mobile phones [1]. A study of first year high school students in Brisbane, Australia revealed that $14 \%$ of students had been harassed by mobile phone text messages [24, 25]. Australia had the lowest rate of cyberbullying reported, 10 to $14 \%$, however, the research was limited to mobile phone bullying.

\subsubsection{Prevalence of cyberbullying reported from studies conducted in Canada}

The results from the Canadian studies are listed in rows two through six of table 1. Phase II of the study followed up about the issue of online bullying uncovered in phase I of the study, by surveying students in grades 7 through 11 . The results were that $34 \%$ of the respondents in grades $7-11$ had been victims of bullying and $12 \%$ sexually harassed in the past year [10]. Twenty-seven percent of victims that had been bullied reported being bullied online [10]. Of the respondents who had reported sexual harassment, $70 \%$ of them had been sexually harassed online [10]. Hence, approximately $9.5 \%$ (27\% of the $34 \%$ being bullied) of the total respondents were bullied online and $8.5 \%$ ( $70 \%$ of the $12 \%$ being sexually harassed) of the total respondents were sexually harassed 
online. The percentages of youth that reported being bullied online were much lower than the $23 \%$ that had received e-mail that "said hateful things about others" [17] in phase I of the study.

$\mathrm{Li}$ and Beran surveyed 432 students in grades 7-9 [6]. Thirty-five percent "experienced cyberharassment once or twice" [6] and 23\% experienced it multiple times" [6]. Li surveyed 177 seventh grade students in urban Canada [17]. Approximately one-quarter of the students reported being bullied online [17]. The majority of victims had one to three incidents of cyberbullying [17]. Both studies documented that the percentage of respondents indicating more than one incident of cyberbullying drops from the percentage indicating that they have been cyberbullied once online $[6,17]$.

An estimated $9.5 \%$ to $35 \%$ [6] of Canadian secondary students have experienced cyberbullying depending on demographics, interpretation of the definition of cyberbullying, and whether sexual harassment online is considered cyberbullying. This estimate was based the Young Canadians in a Wired World Survey Phase II, Li and Beran [6], and Li [17] studies. The Li study and the Beran and Li study focused on the middle grades whereas the Young Canadians in a Wired World Study surveyed the grades 7-12 and also included a larger sample of over 5000 students [17].

\subsubsection{Prevalence of cyberbullying reported from studies conducted in the United Kingdom}

The results are displayed in rows seven through nine in table 1. In 2002, National Children's Home, a UK charity, discovered that $25 \%$ of the 11-19 year olds in a United Kingdom national survey had been "bullied or threatened by PC or mobile phone" [19]. A follow-up survey in 2005 of 770 twelve to sixteen year olds, in conjunction with Tesco Mobile, revealed that $20 \%$ of the respondents had been "bullied or threatened by someone using any of the following- e-mail, Internet, chat room, or mobile phone text messaging" [8]. The results of the NCH studies show that cyberbullying decreased from $25 \%$ in 2002 to $20 \%$ in $2005[8,19]$.

Similar to Young Canadians in a Wired World study, the UK Children GoOnline study investigated how 9-19 year olds in the United Kingdom used the Internet. The study found that $33 \%$ of the daily and weekly Internet users survey "received nasty comments via e-mail, chat, instant messaging or text messaging" [9]. The differences in the results of the $\mathrm{NCH}$ and the UK Children Go-Online study may be due to the wording of the question. "Nasty comments" [9] is more specific and easier to understand than "bullied or threatened by email, chat rooms, or mobile phone" [8]. Also, the word threatened may reduce the likelihood of reporting as is the trend with other studies [2].

A trend that is of concern is happy slapping. Happy slapping started in London in late 2004 as a joke where the victim was surprised by someone approaching them and lightly slapping them around their face [16]. The victim's reaction was filmed using a third generation mobile phone and then uploaded to a website on the Internet to brag about the attack [16]. The trend has escalated from horseplay to filming violent acts where people are beaten and killed. Four 
teens were prosecuted in January 2006, for the fatal beating of a man in England $[16,26]$.

It is difficult to estimate the rate of cyberbullying in the United Kingdom. The UK Kids Go-Online surveyed more youth (1511 compared to 770). Based on the UK Kids Go-Online and NCH studies an estimate of cyberbullying is $20 \%$ [8]-33\% [9] for the United Kingdom.

\subsubsection{Prevalence of cyberbullying reported from studies conducted in the United States of America}

The results of studies from the United States are listed in the last five rows of table 1. The rates of cyberbullying varied in the United States from 6\% [2] to $42 \%$ [20]. These results could be attributed to the wording of the questions and the time when the data was collected. The Youth Internet survey required that the respondent be "threatened and embarrassed about a posting or a message" [27] or "feel worried or threatened about online harassment" [27]. The respondent had to feel threatened, worried, or embarrassed which implied that they were affected by the incident, whereas, just responding yes to being bullied online does not imply that the incident had an effect. The affirmative responses may be indicative of the prevalence of the more serious cases of cyberbullying that could lead to serious effects. On the other hand, the estimate of $6 \%$ from the Youth Internet Survey is data from 1999-2000 could be considered outdated [27].

I-Safe is an Internet safety organization in the United States that was established in 1998. During the 2003-2004 school year, i-SAFE conducted a survey of 1,500 students in the United States in grades four through eight. Fortytwo percent of respondents surveyed had "been bullied online once" [2] while almost one-quarter of the respondents "said it happened more than once". Twenty-one percent of the students had received "mean or threatening e-mail or other messages" [2]. Thirty-five percent of the respondents had been threatened online with almost $20 \%$ saying it has happened more than once [2]. A higher percentage of respondents in the i-SAFE survey said that they had been bullied online than had been threatened online or received threatening e-mail messages. The differences in results may be due to the wording of the questions. Hinduja and Patchin studied 1,500 adolescents and found that $33 \%$ of the respondents were victims of cyberbullying [7].

Based on the Youth Internet Survey, Hinduja and Patchin, and i-SAFE studies an estimate of the prevalence of cyberbullying in the United States is 6\% [7] $-42 \%$ [2]. Ybarra determined that older adolescents were victims of cyberbullying in the Youth Internet study [27]. It may be that the prevalence of more serious cases of cyberbullying is higher among older adolescents.

\subsection{Method of cyberbullying}

The mobile phone is the preferred method used by cyberbullies in Europe and Australia, whereas the Internet is the most commonly used method in the United States and Canada. The results of both the 2002 and $2005 \mathrm{NCH}$ studies documented that the mobile phone was the most frequently used method for 
cyberbullying in the United Kingdom [8, 19]. It could be suggested that since Tesco mobile phone sponsored the 2005 study that results may be biased, as more of the participants might have been avid mobile phone users. However, the UK Kids Go-Online survey revealed that the mobile phone was preferred by youth in the United Kingdom to e-mail and instant messaging for communicating with their friends [16].

Although a study by Li in Canada found that cyberbullies use multiple methods, the methods cited were e-mail, chat, and instant messaging which all use the Internet. The methods of cyberbullying in the Hindura and Patchin study were chat rooms, computer text messages, e-mail, and cell phones [7]. Cell phones were used less than one-third as often as e-mail and one-sixth as often as chat rooms [7].

A likely explanation for Australian and European cyberbullies preferring cell phones is that a higher percentage of European and Australian children and adolescents own cell phones. An estimated $97 \%$ of adolescents $12-16$ years old [8] and $81 \%$ of youth 9-19 years old in the United Kingdom [9] own mobile phones. According to the study from the Australian Psychological Society 83\% of the participants owned mobile phones [1]. Forty-five percent of teenagers in the United States have a cell phone [28]. In Canada about $46 \%$ of students in eleventh grade own a cell phone [10].

Another reason why the mobile phone may be the preferred method for cyberbullies is that it can be discretely used in any place at any time by typing text messages without looking at the phone. An unsuspecting adult could easily be unaware that a child with a phone in his pocket is sending a text message. The size and interface of even the smallest Pocket PC does not afford the privacy and secrecy of the cell phone for cyberbullies.

\subsection{Effects of cyberbullying}

Some victims of cyberbullying have been driven to suicide $[3,4,5]$ withdrawn from school $[29,30]$, and murdered the cyberbully [31], while others remain unaffected by it $[7,27]$. The most common feelings reported in Canadian and American studies were anger, sadness, frustration, and fear [6, 7]. Thirty-five percent of the victims in an American study by Hinduja and Patchin and study were not affected by the cyberbullying [7].

Many of the high profile incidents reported by the media have been the result of website postings. Traditional bullying attacks have an audience that is confined to the school or local community. However, web postings can be seen by large audiences worldwide, magnifying the humiliation and devastation felt by the victim [32]. A sixth-grade girl was killed by a classmate at school in Sasebo, Nagasaki near Japan [31]. The motivation for the fatal stabbing was that the victim had posted offensive messages about the attacker on a website bulletin board [31]. In Canada, teenagers were able to upload a video to the Internet of a 15 year old classmate portraying a Star Wars fighter character with millions viewing the scene online [33, 34]. The teenager dropped out of school and required psychiatric hospitalization from the humiliating incident $[30,33]$. 
The two examples presented demonstrate how a single incident of cyberbullying can have devastating effects and how situations can escalate in the virtual world.

Children and adolescents often view the online world as separate from the offline world [32]. They do not realize that what they communicate in e-mail, text messages, and web postings online can affect others after the online session in the physical world. The fatal stabbing of the sixth grade girl was a tragic event that took place in the physical world that was precipitated by a website posting, an online event. Teachers in British school have had bullying incidents in school that were precluded by offensive online exchanges the night before [35]. There has been a rise in serious violent attacks in British schools to warrant an investigation by the Children's Commissioner [35].

Although rumours spread fast with word of mouth, they are not able to reach as many people in such a short period of time as they would with text messaging [32]. With camera phone technology pictures can be taken instantaneously, capturing the moment to make a joke escalate into intense humiliation for the victim. These large scale rumours and pranks can significantly disrupt the school day [34].

Cyberbullying has been used to augment bullying that is occurring in school. In many cases, the devastating effects may take more time to occur. A 13-year old boy hung himself after being repeatedly harassed by peers [3, 4]. He had been taunted at school, but an investigation of his computer revealed cyberbullying had also played a role in his death [3].

\section{Technological and behavioural measures}

The successful intervention strategies for traditional bullying prevention include setting clear rules and consequences [22, 36, 37], incorporating social skills training in the curriculum [36], parental involvement [22, 36, 37], and intervention services for bullies and victims [22, 36, 37]. The major differences between cyberbullying and traditional bullying are that the bully does not have to see the victim's reaction to the harassment [32], the bully can remain anonymous [32], the harassment can occur at anytime [32], and the audience has the potential of being worldwide [32]. Parents are not currently familiar with cyberbullying, but this aspect of cyberbullying will change with time. Many of the strategies that were successful with traditional bullying could be applied to cyberbullying.

Schools need to educate students and parents about cyberbullying. They need to inform parents and students of acceptable computer use policies in writing at the beginning of the school year and reinforce these polices throughout the school year. It is recommended that there be a clause in the policy allowing school officials to discipline students for violating the acceptable use policies when not using school computers under certain circumstances [22]. These circumstances could include actions that will or have jeopardized the safety of other students at school or disrupted the school day [22]. The policies should be posted in areas where there are computers. A minimum suggested penalty for students violating acceptable use polices is that they loose their computer 
privileges. Schools could monitor student's computer activities similar to the way employers monitor employees computer activities using a package such as Spectorsoft [38].

Education about how to use the Internet should begin in elementary school. Incorporating Internet safety, Netiquette, and discussions about cyberbullying into the school curriculum could be effective raising awareness and preventing cyberbullying similar to social skills training that was effective in conventional bullying prevention programs [36].

Children and adolescents have learned to use the Internet by trial and error or from their friends $[9,10]$. Driver's education is required in many American high schools for graduation. The last people American parents want to teach their teenager how to drive is their friends. Perhaps parents and schools should exercise the same caution about teaching their children to surf the information highway as they do about teaching teenagers to drive a car on the highway. There are consequences for teenagers who abuse their driving privileges. A common punishment for teenagers who do not follow the rules for using the car is to ground them and not allow them to drive the car. Teenagers will also be held accountable by law enforcement officials for traffic violations. It seems logical that parents should set rules and establish consequences for children and adolescents who bully online.

By not having Internet access kids feel as though they are socially isolated [32], a fear parents do not understand. With the stigma of losing cell phone and Internet privileges, this would be the perfect punishment for cyberbullies. The punishment would need to be enforced by the parents. Parental involvement was a key feature in successful traditional bullying prevention programs $[22,36],[37]$. Parents would need to take an active role about discussing their online activities. Independent studies in the United States, United Kingdom, and Canada documented that parents and children do not discuss cyberbullying $[6,7,8,9]$.

Showing students how e-mail and mobile phone messages can be traced may deter cyberbullying [9]. Students would know that the Internet is not completely anonymous and that they could be held accountable for their actions. They need to be taught that the Internet is a means of facilitating communication in the physical world rather than a world of its own.

Experts around the world agree that victims need to tell an adult [13, 14]. Even telling a friend is better than not telling anyone. Kids who do not tell an adult fear that they will loose their technology privileges, adults will not understand, and that the situation will not get better [32,35]. There is research to document the concern that adults do not understand cyberbullying, nor think it is a serious problem. In a survey of American parents by Parry Aftab, only 15\% of parents knew what the word cyberbullying meant [2]. According to research conducted in the United Kingdom by Tesco Mobile and $\mathrm{NCH}, 56 \%$ of parents are not worried that their child could be the victim of mobile phone bullying [39].

Real time computerized reporting systems such Text Someone [11] can be used to augment reporting of incidents. Students can forward text message, 
voice mail, and email or call the school 24 hours a day, seven days a week to document cyberbullying incidents. The system has allowed for intervention that would not have taken place if the victim had to initially report the incident in person [35].

As of January 2006, there are no laws that specifically address cyberbullying. Cyberbullying offences can fall under other laws depending on the country $[8,13]$. Victims of cyberbullying should not respond to the cyberbully as cyberbullying can escalate into serious incidents offline [13, 23]. Keeping electronic and printed evidence to document incidents and reporting serious incidents to law enforcement officials is recommended [13, 23]. As with other issues pertaining to the governance of the Internet, laws and precedents will evolve over time.

\section{References}

[1] Psychosocial Aspects of Mobile Phone Use Among Adolescents; Australian Psychological Society, http://www.psychology.org.au/news/ mobilephoneresearchreport.pdf

[2] Cyberbullying: Statistics and Tips; iSafe America, Inc., http://www.isafe.org/channels/sub.php?ch=op\&sub id=media cyber bull ying.

[3] If We Only Knew, If He Only Told Us; School Assemblies, http://www.ryanpatrickhalligan.com

[4] When Teasing isn't Funny: The Cost of Bullying; Los Vegas Review Journal, http://www.reviewjournal.com/lvrj_home/2005/Oct-31-Mon2005/living/4038822.html

[5] Teenage Victim of Mobile Phone Bullying Dies Clutching Mobile Phone; The

Telegraph, http:/www.telegraph.co.uk/news/main.jhtml?xml=/news/2000/08/19/ndan i19.xml

[6] Beran, T. \& Li, Q., Cyberharassment A Study of a New Method for an Old Behaviour. J. Educational Computing Research, 32(3), pp. 265-277, 2005.

[7] Research Summary: Cyberbullying Victimization; Cyberbullying.us, http://www.cyberbullying.us/cyberbullying victimization.pdf.

[8] Putting U in the Picture: Mobile Bullying Survey 2005; National Children's Home \& Tesco Mobile http://www.nch.org.uk /uploads/documents/Mobile bullying \%20report.pdf

[9] UK Children Go-Online: A Final Report of Key Project Findings; Economic and Social Research Council, http://www.children-goonline.net.

[10] Young Canadians in a Wired World Phase II: Student Survey; Media Awareness Network and the Canadian Government, http://www.mediaawareness.ca/english/research/YCWW/phaseII/upload/YCWWII_Student Survey.pdf. 
[11] Text Someone: 24/7 Text Message, Phone \& E-Mail Reporting of Bullying, Theft, Crime, or Any Unwanted Behaviour; Text Someone, http://www.textsomeone.com/word/TSO brochure web.doc.

[12] Frank, Mark. Foiling Cyberbullies in the New Wild West. Educational Leadership, December 2005/January 2006, pp. 39-43.

[13] Belsley, B., Cyberbullying: An Emerging Threat to the "Always ON" Generation, Technology Concerns, 1(2) pp. 6-13, 2005.

[14] Stop Cyberbullying: How it Works; Wired Safety.org, http://www.stopcyberbullying.org/how_it_works/direct_attacks.html

[15] Locker room camera-phone bullying on rise in Scandinavia, DMEurope.com,

http://www.dmeurope.com/default.asp?ArticleID=1495\&Print=true

[16] Happy Slapping: Transatlantic Contagion of Home-Grown, MassMediated Nihilism; The London Consortium, http://static.londonconsortium.com/issue01/saunders happyslapping.html

[17] Young Canadian's in a Wired World the Student's View Young Canadians in a Wired World; Media Awareness Network and the Canadian Government, http://www.mediaawareness.ca/english/resources/special initiatives/survey_resources/stude nts survey/yciww students view 2001.pdf.

[18] New Bottle but Old Wine: A Research of Cyberbullying in Schools, University of Calgary, http://www.ucalgary.ca/ qinli/publication/cyber_chb2005.pdf.

[19] National Children's Home; Stop Text Bullying http://www.nch.org.uk/information/index.php? $\mathrm{i}=237$.

[20] Highlights of the Youth Internet Safety Survey Fact Sheet; OJJDP Fact Sheet; Office of Juvenile Justice Department, www.missingkids.com/en_US/documents/internetsafety_surv.pdf.

[21] Limber, S., Addressing Youth Bullying Behaviours. Proceedings of Educational Forum on Adolescent Health and Bullying, eds. M. Fleming, and K. Towey, American Medical Association: Chicago, pp 5-16, 2002.

[22] Bullying in Schools; U.S. Department of Justice, Office of Community Oriented Policing Services (COPS), http://www.cops.usdoj.gov/ mime/open.pdf?Item $=272$.

[23] What Everybody Needs to Know About Cyberbullying, Wired Safety http://depts.washington.edu/trio/virtual/web/cyber.doc.

[24] Martin, M. The Causes and Nature of Bullying and Exclusion in Schools. Education Journal (86) pp.28-30, 2005.

[25] Mobile Phone Group Launches anti-SMS Bullying Campaign; ABC News Online, $\quad \underline{\text { http://abc.net.au/science/news/scitech/SciTechRepublish } 1296}$ 864.htm.

[26] Violent path of "Happy Slapping"; BBC News; http://news.bbc.co.uk/1/hi/uk/4478318.stm.

[27] Ybarra, Michele and Mitchell, K. Online Agressor/Targets, Aggressors, and Targets: A comparison of Associated Youth Characteristics Journal of Child Psychology and Psychiatry Vol. 45(7) pp. 1308-1316, 2004. 
[28] Teens and Technology; Pew/Internet Life, http:/www.pewinternet.org /pdfs/PIP Teens Tech July2005web.pdf.

[29] In-Depth Bullying: Cyber-Byllying; CBC News Online, http:/www.cbc.ca/news/background/bullying/cyber bullying.html

[30] Cyber-bullying; Wikipedia, http://en.wikipedia.org/wiki/Cyber bullying.

[31] Archive of CRN Home Page Topics for Discussion; On the Fatal Stabbing of a Sixth Grade Girl; Childnet Research, http:/www.childresearch.net /cgi-bin/topics/column.pl?no=00215\&page=1.

[32] Violence in Cyberspace Against Children; ECPAT International, http://www.ecpat.net/eng/publications/Cyberspace/PDF/ECPAT Cybersp ace 2005-ENG.pdf.

[33] Cyberbullying Can be Traumatic for Teens; Seattle Times, http://seattletimes.nwsource.com/html/living/2001862072 internetbullyin g23.html.

[34] Internet Bullying; Christian Sciences Monitor, http://www.csmonitor.com /2003/1230/p11s01-legn.htm.

[35] Bullying: Sticks, Stones, and Web Chat; The Independent Online Edition, http://education.independent.co.uk/schools/article328882.ece.

[36] Olweus, D., \& Limber, S. Bullying Prevention Program in D. Elliott (ed.), Blue Prints for Violence Prevention, Institute of Behavioural Science, Regents of the University of Colorado: Boulder, Colorado, 1999.

[37] Nansel, T., Overpeck, M. Pila, R, Ruan, W., Simmon-Morton, B, \& Scheidt, P., Bullying Behaviours Among U.S. Youth: Prevalence and Association with Psychosocial Adjustment, Journal of the American Medical Association, 285(16), pp. 2094-2100, 2001.

[38] Textbullying: Putting $U$ in the Picture; National Children's Home Children's Charities, http://www.nch.org.uk/stories/index.php?i=305.

[39] Spectorsoft, http://www.spectorsoft.com/products/SpectorPro Windows/index.html. 